\title{
JPSE
}

[Journal of Physical Science and Engineering]

\section{Study on Physical Properties of Reduced Graphene Oxide from Heating Coconut Shell}

\begin{tabular}{l}
\hline Received \\
18 November 2016 \\
Revised \\
28 November 2016 \\
Accepted for Publication \\
2 December 2016 \\
Published \\
14 December 2016 \\
\hline
\end{tabular}

\author{
K. W. Mas'udah ${ }^{1 *}$, F. Astuti ${ }^{2}$, Darminto $^{2}$ \\ 1. Faculty of Mathematics and Natural Sciences, Universitas Pesantren Tinggi Darul Ulum, PP. Darul \\ 'Ulum Tromol Pos 10 Peterongan, Jombang, 61481, Indonesia \\ 2. Departement of Physics, Faculty of Mathematics and Natural Science, Institut Teknologi Sepuluh \\ Nopember, Kampus ITS Sukolilo, Surabaya, 60111, Indonesia \\ *E-mail: masudahkusuma@gmail.com
}

\begin{abstract}
A research to determine the solar activity in the months from January to March 2015, and analyze the characteristics of flare on the rotation angle shifting of the sunspot group of sunspot sample observed, has been conducted. The method was observation and descriptive analysis of quantitative data. Determination of coordinates of sunspot was done using the software IDL. These observations were made in the Aerospace Observation Center (BPD) LAPAN Watukosek. Data were analyzed in the form of a sketch-owned BPD Sunspot LAPAN Watukosek, ie sunspot sketch of months from January to March in 2015 and the data was taken from NOAA. The results showed that the flare is not always the case in large class of sunspot groups, however, the small class was able to produce a flare. Most flares ware occur after experiencing a shift angle in the preceding or following although with angles that were not too large $\left(<10^{\circ}\right)$. The highest solar activity was occurred in January 2015 with the appearance of a sunspot group consisting of as many as 130 in 1063 sunspots.
\end{abstract}

Keywords: Sunspot, Flare, IDL (Interactive Data Language)

\begin{abstract}
Abstrak
Telah dilakukan penelitian yang bertujuan untuk mengetahui aktivitas Matahari pada bulan Januari-Maret 2015, serta menganalisis karakteristik terjadinya flare pada pergeseran sudut rotasi Group sunspot dari sunspot sampel yang teramati. Metode yang digunakan adalah observasi dan analisis data kuantitatif deskriptif. Penentuan koordinat sunspot dilakukan dengan memanfaatkan software IDL. Pengamatan ini dilakukan di Balai Pengamatan Dirgantara (BPD) LAPAN Watukosek. Data yang dianalisis berupa Sunspot sket milik BPD LAPAN Watukosek, yaitu sunspot sket bulan Januari-Maret pada Tahun 2015 dan data yang diambil dari NOAA. Hasil pengamatan menunjukkan bahwa flare tidak selalu terjadi pada group sunspot kelas besar, namun kelas kecil pun mampu menghasilkan flare. Sebagian besar flare terjadi setelah mengalami pergeseran sudut pada bagian preceeding atau following meskipun dengan besar sudut yang tidak terlalu besar $\left(<10^{\circ}\right)$. Adapun aktivitas Matahari paling tinggi terjadi pada bulan Januari 2015 dengan munculnya group sunspot sebanyak 130 yang terdiri dari 1063 sunspot.
\end{abstract}

Kata Kunci: Sunspot, flare, IDL (Interactive Data Language)

\section{Introduction}

As an island nation located in the tropics with good agro-climatic conditions, Indonesia including major coconut producing countries in the world. Coconut fruit consists of coconut husk, coconut shell, coconut meat and coconut water. Coconut shell is considered as waste utilization is still less than maximum. Coconut shell is one of the organic material used to produce the carbon element is further produced products such as charcoal and activated charcoal. Coconut shell is a material with a carbon content of $49.86 \%$ (kind of old coconut) which consists of cellulose ((C6H10O5)n) and hemicellulose that have ties hexagonal atomic structure. The bond has been in accordance with Graphene so it can potentially be Graphene by reducing the hydrogen and carbon atoms and make it a one-tier. 
Graphene is an exciting material, having a large theoretical specific surface area (2630 m2g-1), high intrinsic mobility (200.000 cm2v-1s-1) [1,2,3], high young's modulus ( 1.0 Tpa) [4] and thermal conductivity $(\sim 5000 \mathrm{Wm}-1 \mathrm{~K}-1)$ [5], and its optical transmittance $(\sim 97,7 \%)$ and good electrical conductivity merit attention for applications such as for transparent conductive electrodes [6,7], among many other potential applications. Graphene is one of the hottest materials in the scientific community in recent years owing to its unique electronic, optical, mechanical and catalytic properties. This opens up the window of novel applications for electronic devices, such as touch panels, p-n junction materials, flexible thin-film transistors and solar cells [8]. Graphene, a fascinating twodimensional carbon material, has been reported with high conductivity, strong mechanical strength, and extremely high specific surface area [9]. Graphene based material, including reduced graphene oxide (rGO) and functionalized graphene, have been applied in many fields with superior performances, such as catalysis [10], supercapacitors[11], photoelectric materials [12], and adsorbents [13].

It has been reported [14] that The rGO was prepared using heat treatment process at temperature $400 \mathrm{oC}$ for 3 hours, by mixing 5 grams of the powder with $50 \mathrm{ml}$ of distilled water. It can be fully dispersed in water to obtain a yellow-bright aqueous suspension. When the concentration of the solution is changed by using different composition (10 grams of rGO was added to $50 \mathrm{ml}$ distilled water), its color is also changed to yellow, indicates a partial reduction of GO. However, the extent of the reduction is not high even rGO obtained in the process of heating at $400 \mathrm{oC}$ for 4 hours. It was found that the preparing of rGO could also be dispersed in 5 grams into $50 \mathrm{ml}$ distilled water. When 10 grams of rGO was added to $50 \mathrm{ml}$ distilled water, its color changed to yellow-dark. The extent of the reduction is higher than the previous solution. The suspension water after rGO was heated at $400^{\circ} \mathrm{C}$ for 5 hours and then weighed into 5 grams mixed with $50 \mathrm{ml}$ of distilled water. The result show that the suspension become very black. When the concentration was changed to 10 grams into $50 \mathrm{ml}$ of distilled water, it results a deep black suspension, indicates a high extent of reduction of rGO.

Among various methods for obtaining thin films graphene (exfoliation, epitaxial growth, chemical vapour deposition) and $\mathrm{rGO}$, the solution process method reported hitherto has several advantages like low cost, ease of fabrication and large scale application. Many researchers adapt spin coating technique consuming lot of solution even for obtaining thin coating [15]. Spin-coating method is a method of growing a thin film on a substrate by means of liquid dripping into the center of the substrate is rotated. The substrate used was glass. The material used as a thin layer deposited or placed at the center of the substrate either by manual or robotic assistance. The material is poured on the substrate. Spin-coating is based on the assumption that the flow of solution to be in stable condition when the centrifugal force and the force of viscosity.

In this study, variations in the temperature holding time was done on the heating process coconut shell, i.e. $400 \mathrm{oC}$ respectively for 3,4 and 5 hours. Heating was carried out in an air atmosphere free and the result after heating without any rinsing. The sample was blended into distilled water with various concentrations solubility. Then the resulting solution, superimposed on the glass substrate on the film fabrication r-GO coconut shell used a spin-coating method.

\section{Method of Research}

The main materials used in this study are old coconut (Cocus nucifera) shell and destiled water. The apparatus used in this research such as furnace (used as main heating treatment); crucible alumina; ultrasonic washer (used as dissolving the sample); centrifuge (used as precipitation to produce the solution); glass substrates; and spin coating device.

The first procedure was making coconut shell charcoal then crushed and drilled it to obtain powder form. It was heated at $400^{\circ} \mathrm{C}$ in the atmospheric condition, aimed to obtain reduced graphene oxide phase. powder dissolved into distilled water with various concentration: $8 \%, 11 \%$, and $12 \%$.

Film substrate using a glass slide which was cut to the size of $1 \times 1 \mathrm{~cm}$ and washed into $50 \mathrm{ml}$ of alcohol with ultrasonic cleanser for 1 hour. Then the glass substrate was dried over a hotplate at a temperature of $400^{\circ} \mathrm{C}$ for 30 minutes. $\mathrm{r}$-GO solution of coconut shell is coated on the glass substrate by using a spin-coating at a speed of 2000 RPM for 50 seconds.

Characterization used in this research are X-Ray diffractometer (Philips X'pert) to identify rGO phase of the powder of coconut shell after heated at temperature $400^{\circ} \mathrm{C}$, Ultraviolet-Visible to 
determine energy gap of r-GO solution (Genesys 10S UV-VIS Spectrophotometer) and Particle Size Analyzer (Zetasizer nano Z S) with laser wavelength of $632 \mathrm{~nm}$, Fourier Transform Infrared (FTIR) was conducted to determine the composition of the elements of a solution of r-GO coconut shell, and Scanning Electron Microscopy (SEM) was conducted to determine the morphology of rGO charcoal coconut shell heating temperature of $400^{\circ} \mathrm{C}$, the material used as the film. Energy Dispersive X-ray (EDX) was used to assure that it has formed a layer on film rGO coconut shell.

\section{Result and Discussion}

Figure 1 shows the pattern of X-ray diffraction of heating treatment of r-GO at $400^{\circ} \mathrm{C}$ by using holding time 3, 4 and 5 hours. The X-ray diffraction measurement is applied by small angle between $2 \theta=5-55^{\circ}$. The X-ray diffraction data are got by using CuK $\alpha$ radiation $\lambda=1,54056$ Awithstep data $0,04^{\circ}$. Based on Fig. 2a, the visible peak of coconut shell charcoal without heat treatment is identified at $2 \theta=23^{\circ}$. There was a slight shift becomes $2 \theta=25^{\circ}$ in the peak after heated as shown in Fig. $2 \mathrm{~b}, 2 \mathrm{c}$ and $2 \mathrm{~d}$ and also formed a peak at the position $2 \theta=42^{\circ}$. The pattern wide peak around $2 \theta=25^{\circ}$ indicates the reflection of the plane (002). The reflection of reduced graphene oxide phase indicates

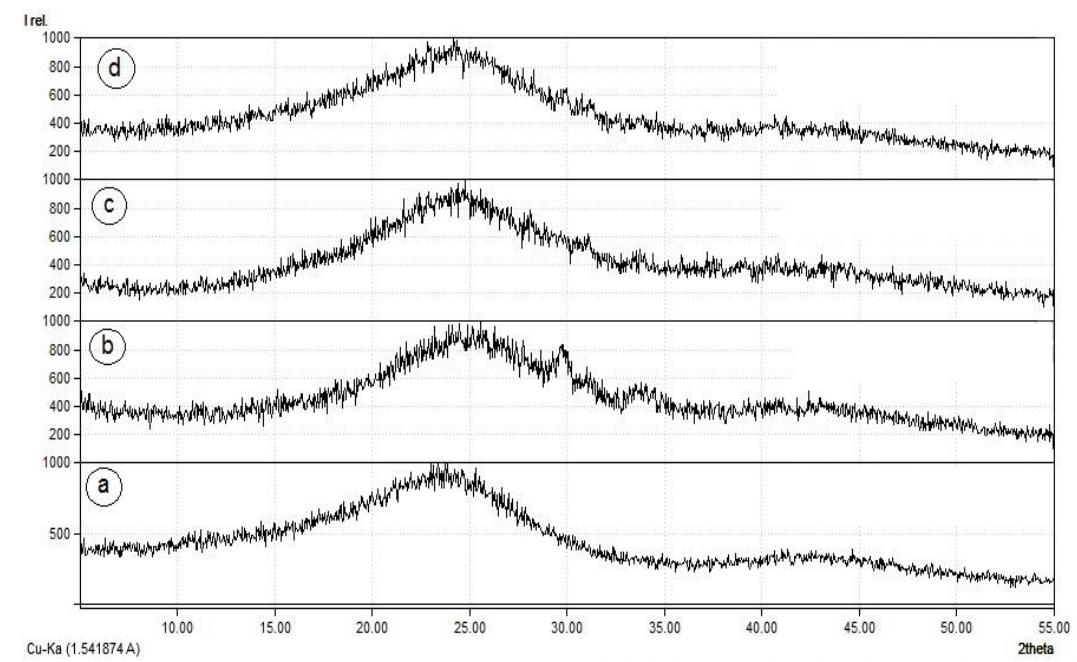

Figure 1. The diffraction pattern of coconut shell charcoal a) before heated, and after heated at $400^{\circ} \mathrm{C}$ for b) $\left.3 \mathrm{~h}, \mathrm{c}\right) 4 \mathrm{~h}$ and d) $5 \mathrm{~h}$

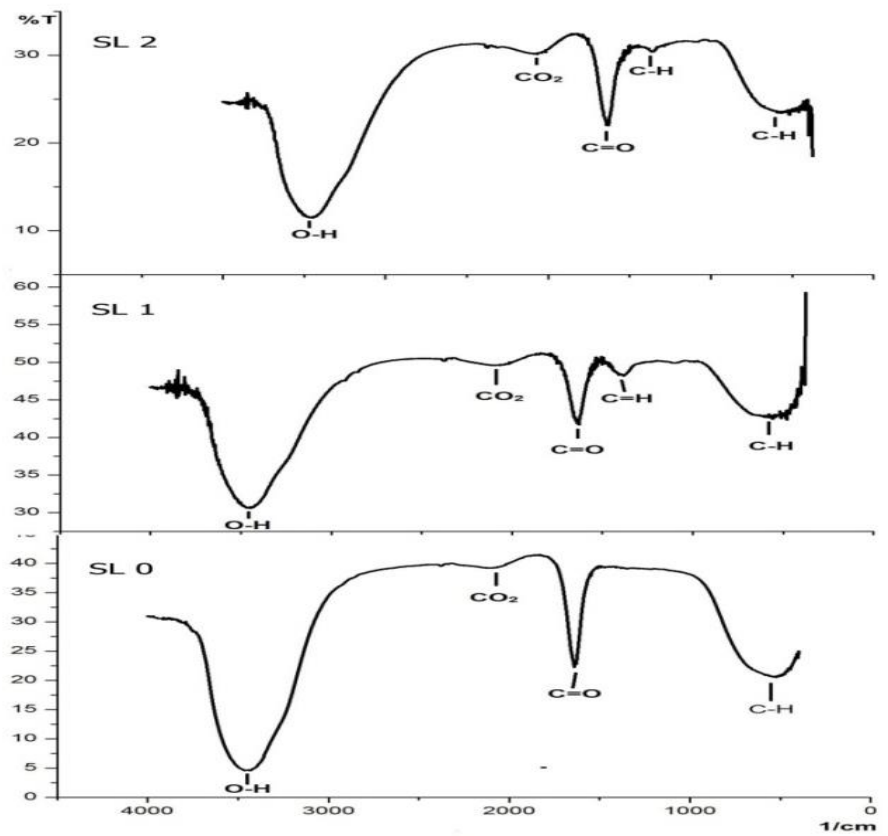

Figure 2. Test Results FTIR on SL-0, SL-1 and SL-2 


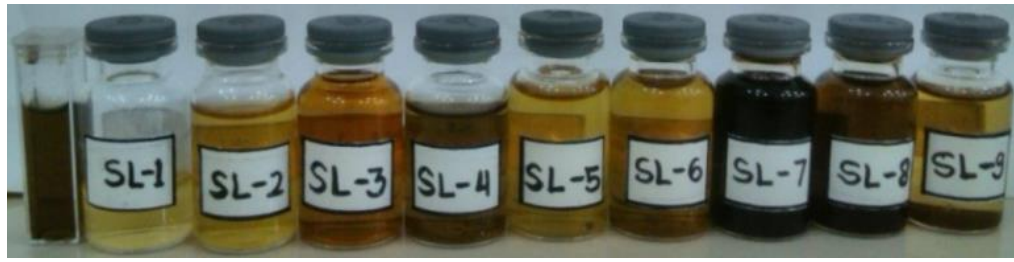

Figure 3.rGO solution Coconut Shell Varying Concentration

the structure of graphite amorphous carbon. The peak which appears at $2 \theta=42^{\circ}$ indicates the phase of cliftonite-2H graphite structure with secondary data PDF 00-041-1487 as the reflection from the plane (100) in the amorphous carbon. It showed a honeycomb (hexagonal) formation of hybridized carbon atoms. Furthermore, the resulted of the peak width of XRD pattern indicates that the crystal size is small r-GO phase. In addition, the peak width indicates that the r-GO layer structure composed in a short span.

Chart pattern in the infrared spectrum of absorption results SL-0 (a solution of coconut shell charcoal), SL-1 and SL-2 is shown in Figure 2. All three samples contained bond peak bending (bending) $=\mathrm{CH}$ located at position 536.17 wave number $\mathrm{cm}^{-1} ; 603.68 \mathrm{~cm}^{-1}$; and $609.46 \mathrm{~cm}^{-1}$. Bending $=\mathrm{CH}$ bond is included in the class alkyne functional group with a wave number range of $600-700 \mathrm{~cm}^{-}$ ${ }^{1}$. Furthermore, the sample SL-1 and SL-2 samples contained small peak bending ties in the field $=\mathrm{CH}$ located at the position wave number 1382.87 and $1357.79 \mathrm{~cm}^{-1}$. C-H bonds are included in the alkene functional group in the aliphatic hydrocarbon. The absence of $\mathrm{C}=\mathrm{C}$ bonds in the sample solution of rGO coconut shell is due to the mixing process by using ultrasonic cleanser for 2 hours, which causes the $\mathrm{C}=\mathrm{C}$ double bond apart. Then, the elements $\mathrm{C}$ binding element $\mathrm{O}$ and $\mathrm{H}$, which is the element of water $\left(\mathrm{H}_{2} \mathrm{O}\right)$.

SL-7 solution that almost approaching jet black is one that has the smallest energy band gap is equal to $(0.73 \pm 0.02) \mathrm{eV}$ with non-homogeneous particle size that is equal to $(191.5 \pm 103.1)$ and $(4314.0 \pm 960.9) \mathrm{nm}$, can be seen in Figure 3. Dark color of the solution indicates the number of r-GO contained in the solution. While the SL-1 solution of bright yellow had the largest energy band gap is equal to $(1.34 \pm 0.10) \mathrm{eV}$ and a particle size of $(468.60 \pm 68.63) \mathrm{nm}$. Bright colors in a solution of $\mathrm{r}-$ $\mathrm{GO}$ indicates impurities in the form of $\mathrm{KCl}$ salt when dissolved in distilled water, then salt impurities fade away on heating with the longer holding time causes the solution to change color and fade to color dark. To assure there is an element of the sample r-GO coconut shell do mapping and EDX.

The results of the energy band gap analysis on a sample film symbol SF-1 to SF-9 is equal to 0.78 to $1.40 \mathrm{eV}$ (can be seen in Table 1). This indicates that the SL-1 and SL-9 in the sample solution and SF-1 to SF-9 on the film sample is a semiconductor material, because the numbers are still below $2 \mathrm{eV}$.

Morphology and element content between the layers of the substrate film r-GO coconut shell can be determined by using SEM test coupled with EDX. Sampling was focused on the powder that has not had impurities when heated at a temperature of $400^{\circ} \mathrm{C}$. When zoomed out looks are stacked layers, Figure 4 shows the layers stacked very much like forming layers arranged in stages. Figure 4 shows that the layer of r-GO coconut shell formed on the glass substrate marked with red color during the process of mapping. This is reinforced by the results of EDX (Figure 5) in the layer stack containing the elements carbon (C) with a weight percentage of $84.55 \%$ and the rest is the element of the glass substrate.

Table 1.The Value of energy gap and particle size of r-GO Solution

\begin{tabular}{|c|c|c|c|c|c|}
\hline No & $\begin{array}{c}\text { Heating } \\
\text { Temperature }\end{array}$ & $\begin{array}{c}\text { Concentration } \\
\text { of Solution }\end{array}$ & $\begin{array}{c}\text { Particle Size } \\
(\mathrm{nm})\end{array}$ & $\begin{array}{c}\text { Energy } \\
\text { Gap }(\mathrm{eV})\end{array}$ & $\begin{array}{c}\text { Thick Layer } \\
(\mu \mathrm{m})\end{array}$ \\
\hline 1 & \multirow{3}{*}{$\begin{array}{c}\mathrm{T}=400^{\circ} \mathrm{C} \\
\mathrm{t}=3 \mathrm{~h}\end{array}$} & $8 \%(\mathrm{SF}-1)$ & $468.60 \pm 68.63$ & $0.78 \pm 0.20$ & $58.7 \pm 8.0$ \\
\hline 2 & & $11 \%(\mathrm{SF}-2)$ & $673.20 \pm 101.50$ & $1.23 \pm 0.10$ & $81.0 \pm 8.0$ \\
\hline 3 & & $12 \%(\mathrm{SF}-3)$ & $\begin{array}{c}329.10 \pm 84.41 \\
5275 \pm 427\end{array}$ & $1.25 \pm 0.10$ & $76.3 \pm 9.5$ \\
\hline 4 & \multirow{2}{*}{$\begin{array}{c}\mathrm{T}=400^{\circ} \mathrm{C} \\
\mathrm{t}=4 \mathrm{~h}\end{array}$} & $8 \%(\mathrm{SF}-4)$ & $\begin{array}{l}183.60 \pm 79.52 \\
4709.0 \pm 774.4\end{array}$ & $0.80 \pm 0.10$ & $46.0 \pm 5.0$ \\
\hline 5 & & $11 \%(\mathrm{SF}-5)$ & $127.10 \pm 60.45$ & $1.12 \pm 0.10$ & $50.8 \pm 5.0$ \\
\hline
\end{tabular}




\begin{tabular}{|c|c|c|c|c|c|}
\hline 6 & & $12 \%(\mathrm{SF}-6)$ & $\begin{array}{l}434.4 \pm 155.9 \\
5296.0 \pm 406,8 \\
220.0 \pm 117,9 \\
4450.0 \pm 906,9 \\
\end{array}$ & $1.25 \pm 0.20$ & $48.0 \pm 4.0$ \\
\hline 7 & & $8 \%$ (SF-7) & $\begin{array}{l}191.5 \pm 103,1 \\
4314.0 \pm 960,9\end{array}$ & $1.20 \pm 0.10$ & $52.4 \pm 4.5$ \\
\hline 8 & $\begin{array}{c}\mathrm{T}=400^{\circ} \mathrm{C} \\
\mathrm{t}=5 \mathrm{~h}\end{array}$ & $11 \%(\mathrm{SF}-8)$ & $\begin{array}{c}306.2 \pm 155,9 \\
4170 \pm 1019 \\
44.76 \pm 10.74\end{array}$ & $1.21 \pm 0.10$ & $51.0 \pm 5.0$ \\
\hline 9 & & $12 \%$ (SF-9) & $202.20 \pm 88.06$ & $1.40 \pm 0.20$ & $45.2 \pm 5.0$ \\
\hline
\end{tabular}

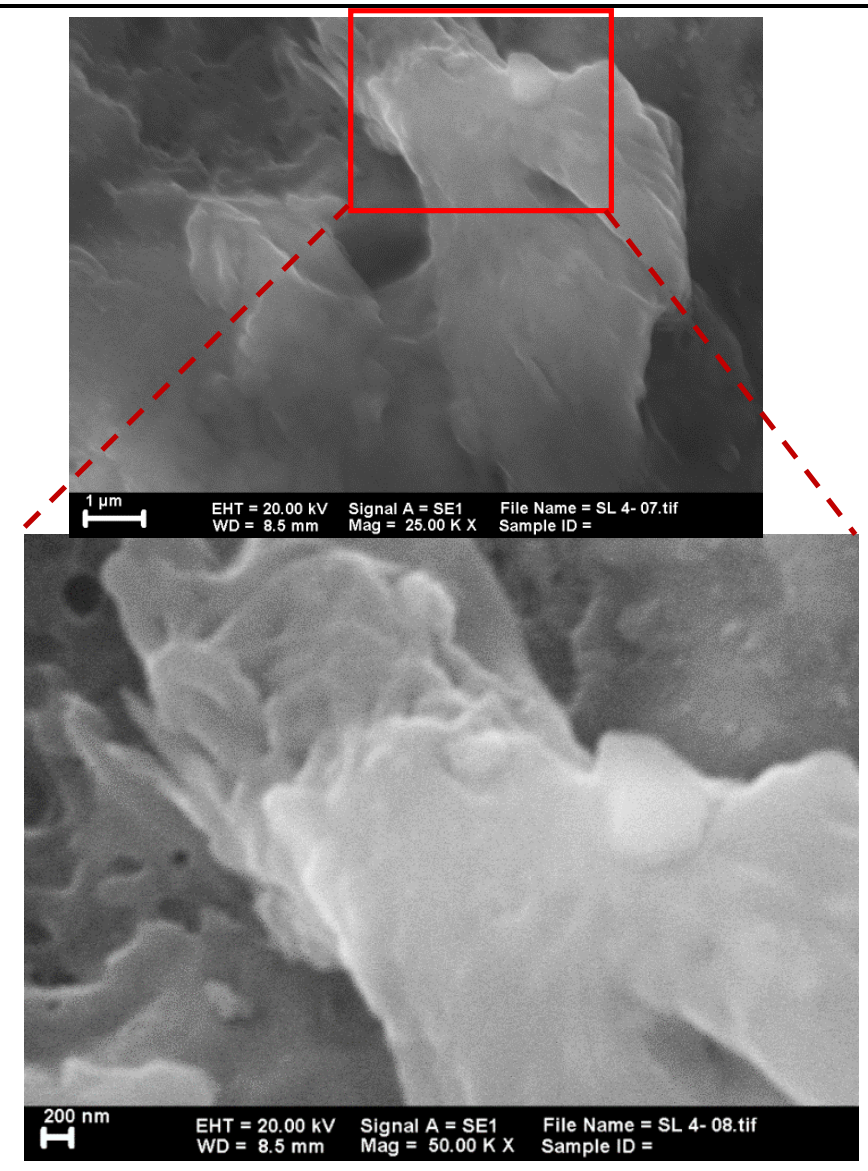

Figure 4. SEM characterization of the SF-4

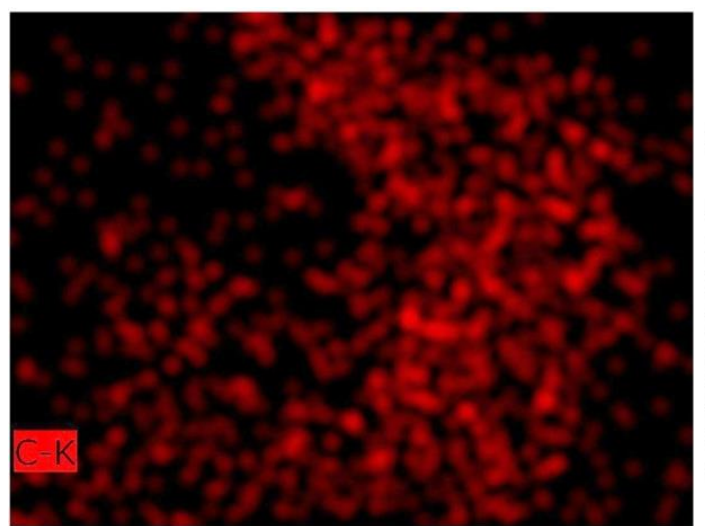

El AN Series unn. C norm. C Atom. C Error $[$ wt. $\%] \quad[$ wt. $\%] \quad[$ at. $\%] \quad[\%]$

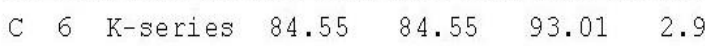

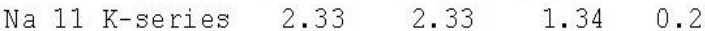

$\begin{array}{lllll}\text { Mg } 12 \mathrm{~K} \text {-series } & 0.45 & 0.46 & 0.25 & 0.1\end{array}$

$\begin{array}{lllll}\text { Si } 14 \mathrm{~K} \text {-series } & 8.60 & 8.60 & 4.04 & 0.4\end{array}$

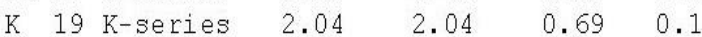

$\begin{array}{llllll}\text { Ca } 20 & \text { K-series } & 2.03 & 2.03 & 0.67 & 0.1\end{array}$

Figure 5.EDX characterization of the SF-4 


\section{Conclusion}

We demonstrated that the study of coconut shell has tremendous potential to be used as the film of $\mathrm{r}$ GO with an environmental benign synthetic protocol. The most important advantages of the coconut shells are their abundance in nature, cost effectiveness and easy product isolation after reduction as they can be taken from non-edible or waste plant products. Film r-GO coconut shell has been successfully made on glass substrates is evidenced and reinforced by the results of mapping and EDX analysis. The value of energy gap, particle size, and high carbon to oxygen ratio of coconut shell are acceptable. Thus spin coating method can be used for large scale production of film r-GO from coconut shell.

\section{References}

[1] Suhartana (2006), Pemanfaatan Tempurung Kelapa Sebagai Bahan Baku Arang Aktif dan Aplikasinya Untuk Penjernihan Air Sumur di Desa Belor Kecamatan Ngaringan Kabupaten Grobogan, Berkala Fisika Vol. 9, No. 3, 151.

[2] K. Geim, K. S. Novoselov (2007), The Rise of Graphene, Nat. Mater., 6, 183.

[3] K. I. Bolotin, K. J. Sikes, Z. Jiang, M. Klima, G. Fudenberg, J. Hone, P. Kim, H. L. Stormer (2008), Ultrahigh Electron Mobility in Suspended Graphene, Solid State Commun., 146, 351 .

[4] S. V. Morozov, K. S. Novoselov, M. I. Katsnelson, F. Schedin, D. C. Elias, J. A. Jaszczak, A. K. Geim (2008). Giant Intrinsic Carrier Mobilities in Graphene and Its Bilayer. Phys. Rev. Lett, 100, 016602 .

[5] Lee, X. D. Wei, J. W. Kysar, J. Hone (2008). Measurement of the Elastic Properties and Intrinsic Strength of Monolayer Graphene, Science, 321, 385.

[6] A. A. Balandin, S. Ghosh, W.Z. Bao, I. Calizo, D. Teweldebrhan, F. Miao, C.N. Lau (2008). Superior Thermal Conductivity of Single-Layer Graphene. Nano Lett., 8, 902.

[7] W. Cai, Y. Zhu, X. Li, R.D. Piner, R.S. Ruoff (2009). Large Area Few-Layer Graphene/Graphite Films as Transparent Thin Conducting Electrodes. Appl. Phys. Lett., 95, 123115.

[8] X. Li, Y. Zhu, W. Cai, M. Borysiak, B. Han, D. Chen, R.D. Piner, L. Colombo, R.S. Ruoff (2009). Transfer of Large-Area Graphene Films for High-Performance Transparent Conductive Electrodes. Nano Lett., 9 , 4359 .

[9] M.J. Allen, V.C. Tung, R.B. Kaner (2010). Honeycomb carbon: a review of graphene. Chem Rev; 110(1), 132.

[10] C. C. Huang. H. Bai, C. Li, G. Q. Shi (2011). A Grapheme Oxide/Hemoglobin Composite Hydrogel for Enzymatic Catalysis in Oraganic Solvents., Chem. Commun. 47 (2011) 4962.

[11] Y. Wang, Z.Q. Shi, Y. Huang, Y.F. Ma, C.Y. Wang, M.M. Chen, Y.S. Chen (2009), Sn@CNT and Sn@C@CNT Nanostructures for Superior Reversible Lithium Ion Storage. Phys. Chem. C. 11313103.

[12] S. Pavagadhi, A.L.L. Tang, M. Sathishkumar, K.P. Loh, R. Balasubramanian (2013). Removal of Microcystin-LR and Microcystin-RR by Graphene Oxide: Adsorption and Kinetic Experiments. Water Res. 474621.

[13] C. Wang, C. Feng, Y.J. Gao, X.X. Ma, Q.H. Wu, Z. Wang (2011), Preparation of a GrapheneBased Magnetic Nanocomposite for The Removal of an Organic Dye from Aqueos Solution. Chem. Eng. J., 17392.

[14] O.G. Apul, Q.L. Wang, Y. Zhou, T. Karanfil. Adsorption of Aromatic Organic Contaminants by Graphene Nanosheets: Comparison with Carbon Nanotubes and Activated Carbon. Water Res. 47 (2013) 1648.

[15] K. W. Mas'udah, I. Md.Ananta, S. Abidin, A. Mufid, F. Astuti, Darminto (2016). Solution of Reduced Graphene Oxide Synthesized from Coconut Shells and Its Optical Properties. AIP Conference Proceedings 1725.

[16] K. W. Mas'udah, F. Astuti, Darminto. Study of Morphology of Film Reduced Graphene Oxide from Coconut Shell, The $1^{\text {st }}$ International Seminar on Science and Technology, ITS Surabaya, Indonesia Proceeding, 1624-177. 